\title{
INŠTITÚT VYDRŽANIA VLASTNÍCTVA NEHNUTELNOSTÍ PO NOVOM
}

INSTITUTE OF ENDURANCE OF REAL ESTATE OWNERSHIP AFTER THE AMENDMENT

\section{Peter Gabrik ${ }^{1}$}

DOI: https://doi.org/10.24040/pros.13.11.2020.ssp.34-42

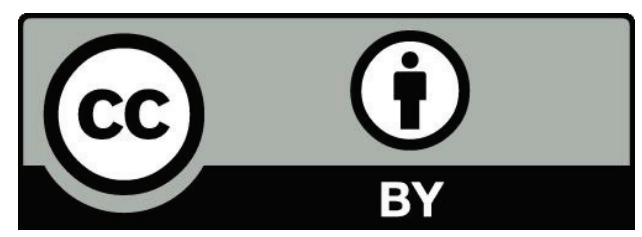

\begin{abstract}
Abstrakt
Inštitút vydržania je zakotvený v právnom poriadku, s prestávkami a zmenami, z dôvodu jeho užitočnosti pri náprave nedostatkov v evidencii vlastníctva nehnutel'ností. Hmotnoprávne je inštitút zakotvený v $\$ 134$ Občianskeho zákonníka. Na faktické zohl'adnenie vydržania v evidencii katastra je však potrebný aj istý procesný postup. Preklenút' vydržanie do platnej evidencie katastra je dnes možné cez osvedčenie vyhlásenia o vydržaní alebo vprípade nesúhlasu posledných evidovaných vlastníkov - sporu, súdnou cestou. Ministerstvo spravodlivosti však chce zrušit’ osvedčenie vyhlásenia o vydržaní a nahradit’ ho súdnym konaním o potvrdení vydržania.
\end{abstract}

\section{Kl’účové slová}

Vydržanie. Nehnutel'nosti. Pozemky. Vlastnícke právo. Držba. Dobromysel'nost'. Dedičstvo. Slovenský pozemkový fond. Lesy SROV. Notár. Súdy. Pol'nohospodárstvo. Orná pôda. Lesy. Vyporiadanie spoluvlastníctva.

\begin{abstract}
The institute of endurance is enshrined in the legislation, with breaks and changes, due to its usefulness in correcting shortcomings in the records of real estate ownership. Substantively, the institute is enshrined in $\$ 134$ of the Civil Code. However, a certain procedure is also necessary to file the maintenance with the cadastre records. Registeration of endurance with the valid cadastre records is now possible through a certificate of declaration of endurance or in case of disagreement of the last registered owners - a dispute, by court action.
\end{abstract}

\footnotetext{
${ }^{1}$ JUDr. Peter Gabrik - Po absolvovaní Právnickej fakulty Univerzity Pavla Jozefa Šafárika v Košiciach pôsobil štyri roky na právnom odbore Slovenského pozemkové fondu, odd. sporovej agendy. Neskôr pôsobil ako advokátsky koncipient $\mathrm{v}$ dvoch advokátskych kanceláriách. $\mathrm{V}$ súčasnosti vykonáva advokátsku prax a zameriava sa na pozemkové právo, právo nehnutel'ností a tiež na medicínske právo. Pôsobí ako externý doktorand na katedre Občianskeho práva Právnickej fakulty Univerzity Pavla Jozefa Šafárika v Košiciach. Je autorom portálu www.neznamyvlastnik.eu.
} 


\section{PRÁVNE ROZPRAVY ON-SCREEN II. - Sekcia súkromného práva}

online vedecká konferencia - 13. november 2020

The Ministry of Justice wants to revoke the certificate of endurance and replace it with court proceedings to confirm endurance.

\section{Keywords}

Endurance. Eeal estate. Land. Ownership. Possession. Goodwill. Heritage. Slovak Land Fund. Forests of the Slovak Republic. Notary. Courts. Agriculture. Arable land. Forests. Settlement of co-ownership.

\section{Úvod}

V odbornej i laickej verejnosti bolo dlhodobo známe, že sa inštitút vydržania často zneužíval, resp. sa k nemu pristupovalo rôzne od prípadu k prípadu. V našich podmienkach rozdrobenosti pozemkov a dedičstva bývalého režimu (kedy boli l'udia odtrhnutí od vlastníctva pôdy) sa javí inštitút vydržania ako užitočný. Z rôznych dôvodov dochádzalo $\mathrm{v}$ minulosti (najmä pred rokom 1989) k právne neperfektným prevodom vlastníckeho práva. Síce sa strany dohodli, vyplatili kúpnu cenu, avšak zmenu vlastníctva nepreviedli do pozemkovej knihy alebo do listu vlastníctva. Pozemky následne v dobrej viere užívali mnoho rokov a prípadne $\mathrm{v}$ takomto užívaní plynule pokračovali ich právni nástupcovia. V prípade zistenia, že pozemky im formálne nepatria, by bolo zrejme nespravodlivé žiadat', aby ich prestali užívat' alebo ich znova odkúpili. Preto má vydržanie zmysel. Nie však v prípade, ked’ sa zneužíva do tej miery, že sa inštitút celkom zdiskredituje. Ministerstvo spravodlivosti SR navrhuje odňat' vydržanie notárom a dat' ho do kompetencie súdom.

\section{I.}

Zmena sa má dotknút’ ustanovenia § 63 zákona č. 323/1992 Zb. o notároch a notárskej činnosti (d’alej aj ako „Notársky poriadok“), v ktorom je upravené osvedčenie vyhlásenia o vydržaní tak, že sa celý $\S 63$ Notárskeho poriadku ruší. Vydržanie postupom podl'a $\S 63$ Notárskeho poriadku sa natol'ko zneužívalo, až bolo potrebné zasiahnut'. Zneužívanie prebiehalo rôznymi spôsobmi v súčinnosti vydržitel'ov a niektorých notárskych úradov. Notári často prehliadali nesplnenie podmienok vyhlásenia o vydržaní, prípadne boli vo svojich postupoch nejednotní až do tej miery, že v rozpore s platným znením zákona 


\section{PRÁVNE ROZPRAVY ON-SCREEN II. - Sekcia súkromného práva}

online vedecká konferencia - 13. november 2020

osvedčovali vyhlásenia o vydržaní vlastníckeho práva. Sú známe mnohé prípady, ktoré sa skončili trestným stíhaním notárov prípadne vydržitel'ov. Poškodený subjekt sa následne vel'mi komplikovane musel domáhat’ nápravy. Napriek tomu, aj po viacnásobnej novelizácii § 63 Notárskeho poriadku, sa nezákonné vydržania nad'alej vyskytovali. Nezákonnost’ spočívala často $\mathrm{v}$ tom, že nebola reálne splnená podmienka dobromysel’nej desat'ročnej držby ${ }^{2}$, prípadne nebol doložený súhlas posledne evidovaného vlastníka resp. jeho nástupcu s vydržaním (v prípade viacerých dedičov všetkých z nich), prípadne ani súhlas správcu. Často boli vydržané pozemky neznámych vlastníkov, ktorí sa nemôžu bránit’.

Problém so zneuživaním inštitútu už otvorene priznáva aj Ministerstvo spravodlivosti SR, ktoré pripravilo novelu Civilného mimosporového poriadku, ktorou chce definitívne odňat' vydržania notárom a zverit' ich do právomoci súdov.

V medzirezortnom pripomienkovom konaní č. LP/2020/361 $3{ }^{3}$ je momentálne (v čase vydania tohto príspevku) návrh novely zákona č. 161/2015 Z. z. Civilný mimosporový poriadok a prebieha vyhodnotenie medzirezortného pripomienkového konania. Novela celkovo ruší § 63 Notárskeho poriadku, teda úplné vyníma vydržanie z činností notárov. Vydržanie má byt' po novom upravené v Civilnom mimosporom poriadku v $§ 359 a$ a nasl. ako Konanie o potvrdení vydržania, teda plne $\mathrm{v}$ právomoci súdov ako napríklad konanie o dedičstve, starostlivost' o maloletých a pod.

II.

Už z názvu nového konania je zrejmé, že ked’že vydržanie je originálnym spôsobom nadobudnutia vlastníckeho práva ${ }^{4}$, je žiadúci vstup orgánu verejnej moci, v tomto prípade súdu, nakol'ko doposial' je vydržanie upravené v § 63 Notárskeho poriadku ako Osvedčenie vyhlásenia o vydržaní. Notársky poriadok radí vydržanie medzi „osvedčenia právne významných skutočností, ktoré by mohli byt' podkladom pre uplatnenie práv, alebo ktorými by mohli byt' spôsobené právne následky“. Notár pri vydržiavaní vlastníckeho práva teda len

\footnotetext{
${ }^{2}$ Najvyšší súd judikatúrou postupne dotvoril podmienky dobromysel'nosti najmä pokial' ide o vstup do držby najmä v judikátoch publikovaných $\mathrm{v}$ Zbierke stanovísk Najvyššieho súdu a rozhodnutí súdov Slovenskej republiky, napr. 4Cdo 283/2009, 4Cdo 361/2012, 4Cdo 21/2004.

${ }^{3} \mathrm{https}: / / \mathrm{www}$. slov-lex.sk/legislativne-procesy/SK/LP/2020/361.

4 ŠTEVČEK, M. A kol.: Občiansky zákonník I. a II. zväzok. Komentár, 2. Vydanie, Bratislava: C.H.Beck, 2019. 1107 s, ISBN: 9788074007705.
} 


\section{PRÁVNE ROZPRAVY ON-SCREEN II. - Sekcia súkromného práva}

online vedecká konferencia - 13. november 2020

procesne upraveným postupom osvedčí, že pred ním dotyčná osoba vyhlásila, že splnila podmienky vydržania podl’a osobitného predpisu ( $\$ 134$ Občianskeho zákonníka) najmä okolnosti odôvodňujúce začatie oprávnenej držby, trvanie a nepretržitost' držby ${ }^{5}$. K vyhláseniu je účastník povinný doložit' potrebné listiny. Ked’že osvedčenie notár vydáva vo forme notárskej zápisnice (ktorá je verejnou listinou), táto je záznamom zapísatel'ná do katastra nehnutel'ností ${ }^{6}$. Tak zásadná právna skutočnost', ako je originálne nadobudnutie vlastníckeho práva by sa podla mienky autora nemala diat' len vyhlásením osoby, hoci pred notárom. Notár za súčasného nastavenia nerozhoduje o vydržaní ${ }^{7}$ ani ho „,nepotvrdzuje“, avšak procesný výsledok je takmer rovnaký, nakol'ko bez osvedčenia vyhlásenia notárom vo forme notárskej zápisnice vyhlásenie oprávnenej osoby nemá praktický význam.

Za súčasného nastavenia de facto o vydržaní rozhoduje notár, ktorý sa však často mohol bránit', že len osvedčuje vyhlásenie účastníka. Ako už bolo uvedené, celé toto nastavenie sa v praxi ukázalo ako nedostatočné. Ministerstvo spravodlivosti SR v dôvodovej správe k novele uvádza:

„Ciel’om návrhu zákona je zmena spôsobu deklarovania vydržania vlastníckeho práva k nehnutel'nosti a práva zodpovedajúceho vecnému bremenu tak, aby bola zabezpečená ochrana vlastníckeho práva za súčasného zachovania princípu právnej istoty. Toto oprávnenie sa vyníma $\mathrm{z}$ právomoci notárov, nakol’ko $\mathrm{v}$ rámci vydávania osvedčení o vyhlásení vydržania notármi boli evidované určité problémy pri aplikácii súčasnej právnej úpravy a $v$ niektorých prípadoch došlo aj $k$ zneužitiu tohto právneho inštitútu na úkor ústavnej ochrany vlastníckeho práva. Aj vzhl'adom na uvedené, ako aj vzhl'adom na samotný charakter právneho inštitútu vydržania vlastníckeho práva $\mathrm{k}$ nehnutel’nosti alebo práva zodpovedajúceho vecnému bremenu, ktorý je špecifický nadobudnutím vecného práva ex lege bez konštitutívneho rozhodnutia príslušného orgánu verejnej moci, sa navrhuje prenesenie tejto právomoci na súd, ktorý v rámci zákonom ustanoveného procesu potvrdí nadobudnutie vlastníckeho práva k nehnutel'nosti alebo práva zodpovedajúceho vecnému bremenu vydržaním, alebo návrh na vydanie takéhoto rozhodnutia zamietne ak zistí, že neboli splnené hmotnoprávne podmienky vydržania navrhovatel'om. $\mathrm{Na}$ účely právnej istoty sa $\mathrm{v}$ rámci konania o potvrdení vydržania zabezpečuje zverejnenie informácie o tomto procese (publicita). Okrem uvedeného sa navrhuje aj zmena právnej

\footnotetext{
${ }^{5}$ VALOVÁ, K. a kol.: Notársky poriadok. Komentár, Bratislava: C.H.Beck, 2016. 687s, ISBN: 9788089603442.

${ }^{6}$ HALAMA, O.: Katastrálny zákon - komentár, Bratislava: Wolter Kluwer, 2014. 87s, ISBN: 9789081680151.

7 ŠTEFANKO, J.: Vydržanie ako právny titul nadobudnutia vlastníctva k nehnutel'nosti v nesporovom konaní, ARS NOTARIA, 4/2001, článok publikovaný a dostný na https://www.notar.sk/Ars/4_2001.pdf.
} 


\section{PRÁVNE ROZPRAVY ON-SCREEN II. - Sekcia súkromného práva}

online vedecká konferencia - 13. november 2020

úpravy týkajúca sa mlčanlivosti notárov a zapožičiavania spisov oprávneným osobám tak, aby došlo k odstráneniu nadbytočnej a neefektívnej administratívnej zát’aže a súčasne aj $\mathrm{k}$ odstráneniu konaní, ktoré smerujú k znemožňovaniu alebo k st’ažovaniu výkonu štátneho dohl'adu nad činnost'ou notárov.“

III.

Ked’že po novom by malo byt' vydržanie samostatným súdnym konaním, je potrebné si zadefinovat' príslušnost' súdu, účastníkov konania, náležitosti návrhu, rozhodnutia a d’alšie procesné pravidlá.

Na konanie bude príslušný súd, v ktorého obvode sa nachádza nehnutel'nost', ktorá sa má vydržat'. Návrh na začatie konania je oprávnený podat' ten, kto o sebe tvrdí, že vydržaním nadobudol vlastnícke právo $\mathrm{k}$ nehnutel’nosti alebo právo zodpovedajúce vecnému bremenu. Účastníkom konania má byt’ aj ten, kto má v čase začatia konania o potvrdení vydržania zapísané na liste vlastníctva vlastnícke právo alebo vecné právo k nehnutel’nosti, ktorej sa konanie o potvrdení vydržania týka. V prípade neznámych vlastníkov je účastníkom aj Slovenský pozemkový fond resp. Lesy SR, š.p.

Návrh na začatie konania o potvrdení vydržania musí okrem všeobecných náležitostí návrhu obsahovat' opísanie skutočností, z ktorých vyplýva, že navrhovatel' splnil predpoklady pre nadobudnutie vlastníckeho práva $\mathrm{k}$ nehnutel'nosti alebo práva zodpovedajúceho vecnému bremenu vydržaním, označenie nehnutel’nosti podl'a údajov z katastra nehnutel'ností a označenie dňa, kedy navrhovatel' nadobudol vlastnícke právo $\mathrm{k}$ nehnutel'nosti alebo právo zodpovedajúce vecnému bremenu vydržaním. Skutočnosti podl'a predchádzajúcej vety musí navrhovatel' zároveň osvedčit'. Ked’že ide o mimosporové konanie v zmysle Civilného mimosporového poriadku, súd je oprávnený vykonat' aj také dôkazy, ktoré navrhovatel' nenavrhol alebo nedoložil ${ }^{8}$.

Súd bude mat' v prvej fáze možnost' odmietnut' návrh, ak bude podaný neoprávnenou osobou alebo bude zjavne neopodstatnený. Po preskúmaní podkladov môže súd návrh ešte aj zamietnut', ak síce návrh podala oprávnená osoba a nejde o zmätočné podanie, ale napr. z doložených podkladov alebo zo súdom zabezpečených podkladov vyjde najavo, že

\footnotetext{
8 SMYČKOVÁ, R. a kol.: Civilný mimosporový poriadok, Bratislava: C. H. Beck, 2017, 65s. ISBN: 9788089603541.
} 
PRÁVNE ROZPRAVY ON-SCREEN II. - Sekcia súkromného práva

online vedecká konferencia - 13. november 2020

navrhovatel' nemohol užívat' pozemok po dobu 10 rokov, prípadne že nemohol byt' dobromysel'ný pri vstupe do držby a pod. Ak súd návrh odmietne alebo zamietne, neupovedomuje o tom žiadneho d’alšieho účastníka konania okrem navrhovatel'a.

Ak súd po predbežnom posúdení návrhu nevzhliadne zásadné rozpory, vydá tzv. Vyzývacie uznesenie. Vo vyzývacom uznesení (v ktorom je popis nehnutel’ností a dôvodov vydržania) súd vyzve na uplatnenie námietok proti vydaniu uznesenia o potvrdení vydržania v lehote najmenej 6 mesiacov.

Vyzývacie uznesenie sa zverejní jednak:

- verejnou vyhláškou v Obchodnom vestníku,

- na úradnej tabuli obce, v katastrálnom území ktorej je nehnutel’nost'; verejná vyhláška môže byt' zverejnená aj prostredníctvom hromadných oznamovacích prostriedkov,

okrem toho sa Vyzývacie uznesenie doručuje (okrem navrhovatel'a):

- vlastníkovi zapísanému na liste vlastníctva, a to do vlastných rúk.

- $\quad$ v prípade, že ide o neznámych vlastníkov, doručuje sa Vyzývacie uznesenie aj správcom, Slovenskému pozemkovému fondu a Lesom SR, š.p..

Naviac sa do katastra zapíše informatívna poznámka (na základe zverejnenia uznesenia v Obchodnom registri), že vo vzt’ahu k tejto nehnutel'nosti je vedené konanie o potvrdení vydržania, resp. že bolo vydané vyzývacie uznesenie.

Teda o Vyzývacom uznesení by sa mali dozvediet' dotknuté subjekty na ovel’a lepšej platforme, ako tomu je za súčasných podmienok. Zverejnenie v Obchodnom vestníku a na úradnej tabuli v obci má za ciel', aby svoje námietky mohli vznášat' aj iné subjekty, ktoré majú vedomost', že neboli splnené podmienky vydržania.

Všetky uvedené osoby a teda ktokol'vek, kto má relevantné informácie, môže podat' námietky na súd v uznesením stanovenej lehote. Ak sú tieto relevantné, súd návrh ako taký zamietne. Pred zamietnutím môže vykonat' d'alšie dokazovanie na preverenie tvrdení z námietok prípadne môže na ten účel nariadit’ aj pojednávanie. Súd potvrdí vydržanie, len ak v zmysle dokazovania budú preukázané podmienky pre vydržanie a nebudú podané žiadne námietky, alebo sa ukážu ako nedôvodné. 


\section{PRÁVNE ROZPRAVY ON-SCREEN II. - Sekcia súkromného práva}

online vedecká konferencia - 13. november 2020

IV.

Je zrejmé, že celý popísaný procesný postup je kvalitatívne na inej úrovni, ako je tomu dnes pri osvedčovaní vydržania. Vecou sa zaoberá súd, vyhodnocuje vznesené námietky, vykonáva dokazovanie a môže nariadit’ pojednávanie. V súčasnosti sa dotknuté osoby často môžu dozvediet' o vydržaní až v čase, kedy je už vlastnícke právo na liste vlastníctva zmenené. Nikto nevyhodnocuje nezávisle a vo všetkých súvislostiach splnenie podmienok pre vydržanie. Súdne rozhodnutie vydané po predpísanom procese ovel'a viac chráni ústavné práva vlastníkov zapísaných na liste vlastníctva.

Aj $\mathrm{v}$ tomto na prvý pohl'ad vhodnom a potrebnom zásahu do právnej úpravy je potrebné upozornit’ aj na riziká. Tie spočívajú v zmeškaní lehoty na podanie námietok. Ak na liste vlastníctva zapísaná osoba prevezme Vyzývacie uznesenie do vlastných rúk a nepodá námietky do vydania uznesenia o potvrdení vydržania alebo, bude t’ahat’ za kratší koniec, hoci by mal relevantné dôkazy o nesplnení podmienok vydržania. $O$ to viac by mali aj iné osoby venovat' pozornost' Obchodnému vestníku, úradnej tabuli alebo evidencii katastra, nakol'ko im sa Vyzývacie uznesenie nedoručuje priamo.

Ak totiž súd uznesením potvrdí vydržanie (súčasne toto rozhodnutie nadobudne právoplatnost'), a vydržitel' prevedie ním potvrdené vlastnícke právo následne na tretiu osobu, je tento nový vlastník chránený tak, akoby toto vlastníctvo nadobudol od oprávneného vlastníka. Toto pravidlo naráža na dlhotrvajúcu právnu polemiku, koho právo je silnejšie. Či právo vlastníka, ktorému v rozpore so zákonom (absolútne neplatným právnym úkonom) bolo vlastnícke právo prepísané na inú osobu, alebo právo dobromysel'ného nadobúdatel'a, ktorí nehnutel'nost' kúpil v dobrej viere, zaplatil na n̆u a nemal vedomost' o spornosti vlastníckeho práva9 ${ }^{9}$ Pre prípad tohto nového konania o potvrdení vydržania sa zákonodarca rozhodol túto spornost' explicitne pre tento prípad vyriešit'.

Preto ak už súd potvrdí vydržanie a nadobúdatel' nehnutel'nost' predá, bude pôvodný vlastník v slabšej pozícii. Bude musiet' preukázat', že nadobúdatel' nehnutel'nosti vedel alebo mal vediet', že vydržitel' klamal pri návrhu resp. že mu súd vydržanie potvrdil v rozpore so zákonom. Ak toto nepreukáže, súd bude chránit’ nového vlastníka.

\footnotetext{
${ }^{9}$ Právny vývoj v tejto otázke je zrejmý aj z judikatúry (pôvodne prevládanie zásady nemo plus iuris ad alium transferre potest quem ipse habet) Ústavného súdu SR v uznesení I. ŮS 50/2010 zo dňa 10. Februára 2010 a inklinácia k väčšej ochrane dobromysel'ného nadobúdatel’a v náleze I. ÚS 549/2015 zo 16. marca 2016 alebo náleze II. ŮS 484/2015 zo dňa 14.11.2018.
} 


\section{PRÁVNE ROZPRAVY ON-SCREEN II. - Sekcia súkromného práva}

online vedecká konferencia - 13. november 2020

Kým vydržitel' neprevedie súdom priznanú nehnutel'nost' na tretiu osobu, bude môct' aj po zmeškaní lehoty podat' účastník konania na súd žalobu a domáhat' sa svojho vlastníckeho práva, len ak osvedčí, že skutočnosti a námietky, na ktorých žalobu zakladá, nemohol bez svojej viny uplatnit' námietkami podl’a tohto zákona.

Riziko alebo malá nevýhoda oproti súčasnému zneniu je v tom, že dnes v prípade nezákonného vydržania je možné podat' určovaciu žalobu na súd a domáhat' sa svojho vlastníckeho práva s použitím všetkých relevantných dôkazov. Súd za súčasného znenia nemá zakotvené pravidlo chránit' dobromysel'ného nadobúdatel'a, ak vydržitel' nezákonné vydržanú nehnutel'nost' prevedie na tretiu osobu. Novelu je teda možné vnímat' aj tak, že pred potvrdením vydržania d’aleko viac chráni zapísaného vlastníka, avšak ak si tento neodôvodnenie neuplatní v konaní svoje nároky, neskôr bude v slabšej pozícii oproti dnes platnému právnemu nastaveniu.

\section{Záver}

Ministerstvo spravodlivosti sa rozhodlo riešit' neblahú prax, kedy sa často zneužíval inštitút vydržania. Tento krok hodnotím ako vysoko žiadúci, nakol'ko súčasná právna úprava je už zjavne nedostatočná. Aby sa úplne nezrušil inštitút vydržania, bola zvolená kvalitatívne lepšia forma, a to súdne rozhodnutie. Novela zákona je v štádiu pripomienkovania a nie je ešte legislatívnom procese v Národnej rade SR. Preto je nevyhnutné počkat' na definitívne schválenie zmien.

Je potrebné vyslovit’ nádej, že navrhované zmeny budú schválené a teda napomôžu lepšej ochrane vlastníckeho práva dotknutých subjektov. Neporovnatel'ne by sa zvýšila transparentnost' vydržania a máme za to, že by boli potvrdené skutočne len tie vydržania, ktoré sú dôvodné a nebudú sa cez tento inštitút oberat' vlastníci o nehnutel'nosti. Na liste vlastníctva evidovaní vlastníci však budú musiet' včas vzniest' svoje námietky. 
PRÁVNE ROZPRAVY ON-SCREEN II. - Sekcia súkromného práva

online vedecká konferencia - 13. november 2020

\section{ZOZNAM BIBLIOGRAFICKÝCH ODKAZOV}

HALAMA, O.: Katastrálny zákon - komentár, Bratislava: Wolter Kluwer, 2014. 178s, ISBN: 9789081680151 .

PEKÁREK, M. a kol.: Pozemkové právo, Bratislava: Aleš Čeněk, 2020. 336s ISBN: 9799077882122.

SMYČKOVÁ, R. a kol.: Civilný mimosporový poriadok, Bratislava: C.H.Beck, 2017, 1112s. ISBN: 9788089603541.

ŠTEFANOVIČ, M.: Pozemkové právo, Bratislava: Eurounion, 2006. 300s, ISBN: 8088984920.

ŠTEVČEK, M. a kol.: Občiansky zákonník I. a II. zväzok. Komentár, 2. Vydanie, Bratislava: C.H.Beck, 2019. 3344s, ISBN: 9788074007705.

VALOVÁ, K. a kol.: Notársky poriadok. Komentár, Bratislava: C.H.Beck, 2016. 816s, ISBN: 9788089603442.

VOJČÍK, P.: Občianske právo hmotné. Bratislava: Aleš Čeněk, 2018. 764s ISBN: 9788073807191 . 